\title{
FAKTOR-FAKTOR YANG MEMPENGARUHI KINERJA KARYAWAN DI SEKOLAH METHODIST BANDA ACEH
}

\author{
Stephen Oktovian dan Edalmen \\ Program Studi Manajemen Fakultas Ekonomi Universitas Tarumanegara, Jakarta \\ stepheno.em@stu.untar.ac.id
}

\begin{abstract}
This study aims to analyze the effect of perceived organizational support, organizational justice, and affective commitment on employee performance at the Banda Aceh Methodist School. The data was obtained through a questionnaire with sampling using a saturated sample technique that used the entire population to be a sample of 62 respondents. Data analysis using SmartPLS software version 3.0. The results showed that perceptions of organizational support, organizational justice and affective commitment had a positive and significant effect on employee performance.
\end{abstract}

Keywords: Perceived Organizational Support, Organizational Justice, Affective Commitment, and Employee Performance

\begin{abstract}
Abstrak: Penelitian ini bertujuan untuk menganalisis pengaruh persepsi dukungan organisasi, keadilan organisasi, dan komitmen afektif terhadap kinerja karyawan di Sekolah Methodis Banda Aceh. Data diperoleh melalui kuisioner dengan pengambilan sampel menggunakan teknik sampel jenuh yang menggunakan keseluruhan populasi menjadi sampel sebanyak 62 responden. Analisis data menggunakan software SmartPLS versi 3.2. Hasil penelitian menunjukkan bahwa persepsi dukungan organisasi, keadilan organisasi dan komitmen afektif berpengaruh positif dan signifikan terhadap kinerja karyawan.
\end{abstract}

Kata Kunci: Persepsi Dukungan Organisasi, Keadilan Organisasi, Komitmen Afektif, dan Kinerja Karyawan

\section{LATAR BELAKANG}

Seiring dengan berkembangnya ilmu pengetahuan dan teknologi merupakan suatu kewajiban bagi organisasi untuk memiliki keunggulan dalam bersaing. Peningkatan dalam sumber daya manusia menjadi salah satu strategi untuk bertahan dalam menghadapi persaingan. Hal ini terjadi dikarenakan suatu organisasi yang memiliki kemampuan kerja yang baik atau sesuai dengan standar maka pada akhirnya organisasi tersebut memiliki kekuatan untuk bertahan di dalam persaingan (Fatdina, 2009). Tetapi suatu hal yang perlu diketahui bahwa untuk memiliki ketahanan dalam menghadapi persaingan tentunya hal ini memiliki keterkaitan dengan kemampuan yang dimiliki oleh sumber daya manusia di dalamnya. Sumber daya manusia merupakan penggerak utama suatu organisasi dan dapat membawa organisasi untuk mencapai tujuannya (Setyaningdyah et al, 2013). Dengan demikian dapat dikatakan apabila suatu organisasi melakukan pengendalian yang benar terhadap sumber daya manusia di dalamnya, tentu hal tersebut dapat memberikan keuntungan bagi organisasi tersebut. Salah satu keuntungan yang dapat didapat adalah peningkatan kualitas kinerja organisasi seiring berjalannya waktu.

Pengembangan sumber daya manusia tidak lepas dari peran aktif manajemen yang mengupayakan peningkatan produktivitas kerja karyawan dan perusahaan. Kebutuhan dalam 
peningkatan upah, tunjangan, pelatihan, pengembangan karir perlu dipertimbangkan dan diperhatikan dengan baik. Kinerja melahirkan hasil kerja yang baik dari segi kualitas maupun kuantitas yang telah digapai seseorang dalam melaksanakan tugas sesuai tanggung jawab yang telah diberikan (Mangkunegara, 2008). Kinerja sumber daya manusia di dalamnya dapat memberikan pengaruh terhadap keberhasilan organisasi.

Kualitas kinerja sumber daya manusia dalam organisasi atau perusahaan dapat meningkatkan dipengaruhi oleh beberapa faktor. Salah satunya adalah faktor dukungan yang diberikan oleh organisasi. Dukungan yang diberikan oleh organisasi atau perusahaan dapat memberikan pengaruh positif terhadap kualitas kinerja sumber daya manusia. Pengaruh positif yang dimaksud adalah para pekerja tersebut dapat menciptakan hasrat yang positif untuk dapat menyelesaikan segala pekerjaan dengan baik dan sesuai dengan standar perusahaan. Beberapa dukungan yang diberikan oleh organisasi atau perusahaan dapat berupa kenaikan upah kerja, penyediaan fasilitas untuk mendukung proses kerja karyawan, promosi kenaikan jabatan dan sejenisnya. Penelitan yang dilakukan oleh Rismanto (2020), Mujibburahman et.al (2020)., Ariarni dan Afrianty (2017), Murniasih \& Sudarma (2016), dan Agustiningrum (2016) menunjukkan bahwa terdapat pengaruh positif dan signifikan dukungan organisasi terhadap kinerja karyawan. Sedangakan penelitian Purnami (2017) menemukan hasil yang berbeda dimana dukungan organisasi mempunyai pengaruh positif namun tidak signifikan terhadap kinerja karyawan

Perlakuan adil yang diberikan oleh organisasi kepada setiap karyawan akan mampu membentuk situasi kerja yang baik, sehingga karyawan merasa nyaman dan memiliki keinginan untuk bekerja lebih baik di dalam perusahaan. Menurut Panggabean (2004) keadilan organisasipada hakikatnya adalah pemahaman individu terhadap perlakuan yang mereka peroleh di tempat kerja. Perlakuan tersebut akan mempengaruhi sikap dan perilaku karyawan yang pada akhirnya sangat berdampak pada keberhasilan organisasi. Menurut Sutrisna dan Rahyuda (2014) keadilan organisasi merupakan suatu konsep keseimbangan yang diharapkan mampu diaplikasikan dan diwujudkan oleh organisasi dalam memperlakukan karyawannya dengan maksud memicu tumbuhnya rasa berkomitmen didalam diri karyawan. Hasil penelitian dari Mujibburahman, et al (2020), Razi (2019) dan Kholis (2017) menyimpulkan bahwa keadilan organisasi mempunyai pengaruh positif dan signifikan terhadap kinerja karyawan. Adapun penelitian yang dilakukan oleh Fazjerin (2018) menemukan bahwa keadilan distributif dan prosedural tidak berpengaruh terhadap kinerja karyawan

Dukungan yang diberikan organisasi atau perusahaan kepada karyawan apabila sudah memiliki kesesuaian dengan harapan para pekerja maka pada akhirnya para pekerja tersebut secara langsung maupun tidak langsung sudah memiliki perasaan yang puas dikarenakan harapan yang diinginkan sudah tercapai. Apabila para pegawai sudah memiliki perasaan yang puas ataupun senang terhadap organisasi tersebut maka pada akhirnya akan tercipta komitmen afektif (Han et al., 2012). Komitmen afektif dapat terpelihara dengan baik di dalam diri pegawai atau para pekerja apabila perusahaan atau organisasi terkait dapat memberikan segala sesuatu yang dapat meningkatkan kepuasan para pekerja. Jika kepuasan karyawan meningkat maka seiring berjalannya waktu maka akhirnya mereka dapat semakin loyal terhadap organisasi atau perusahaan terkait. Bukan hanya loyal, namun para pegawai tersebut dapat menciptakan komitmen yang konsisten untuk melaksanakan aktifitas kerja dengan baik sesuai dengan standar yang berlaku dan dapat meningkatkan kinerja mereka. Hasil penelitian yang dilakukan oleh Mohamad \& Tony Nawawi (2020), Avera \& Tony Nawawi (2019), Purnami (2017), Akbar dkk (2017), Murniasih \& Sudarma (2016), dan Anisah (2016) menemukan 
bahwa komitmen organisasi berpengaruih positif dan signifikan terhadap kinerja karyawan. Adapun hasil penelitian dari Dewi (2019) menyatakan bahwa komitmen afektif secara parsial tidak mempunyai pengaruh terhadap kinerja karyawan.

Kinerja karyawan yang baik akan menciptakan hasil yang baik juga. Sektor pendidikan juga tidak terkecuali juga harus memiliki kinerja yang baik karena dampaknya yang langsung dirasakan oleh murid sebagai penuntut ilmu di sekolah. Pada saat ini banyak sekali organisasi masyarakat maupun yayasan sosial yang ikut didalam membangun pendidikan di Indonesia dengan membentuk sarana pendidikan seperti sekolah dari tingkat dasar hingga perguruan tinggi. Lembaga Pendidikan Swasta dapat berupa yayasan yang dikelola oleh yayasan itu sendiri. Perguruan Kristen Methodist Indonesia yang berada di Banda Aceh merupakan salah satunya. Untuk peningkatan mutu dan hasil pembelajaran siswa, guru di Sekolah Methodist Banda Aceh diharuskan memiliki kinerja yang baik. Dibutuhkan guru-guru yang memiliki rasa dedikasi yang tinggi dalam mengajar dan membimbing siswa. Para guru di Sekolah Methodist Banda Aceh pun harus secara rutin mengikuti pelatihan dan pendidikan untuk peningkatan kualitas pengajaran di kelas. Tujuan penelitian ini adalah untuk mengetahui pengaruh persepsi dukungan organisasi, keadilan organisasi, dan komitmen afektif terhadap kinerja karyawan di Sekolah Methodist Banda Aceh.

\section{KAJIAN TEORI}

Persepsi atau pandangan dukungan organisasi merupakan pandangan yang diciptakan oleh para pekerja di dalam perusahaan atau organisasi terkait bagaimana sebuah organisasi atau perusahaan memberikan perlakukan yang baik dan adil kepada sumber daya manusia di dalamnya. (Rhoades \& Eisenberger, 2002). Jika karyawan merasakan dukungan organisasi yang diterima nya sesuai dan tinggi, maka karyawan tersebut akan membentuk status keanggotaannya sebagai anggota organisasi ke dalam identitas diri karyawan tersebut sehingga menghubungkan hubungan dan persepsi yang lebih ke arah positif terhadap organisasi tersebut. Dukungan organisasi dapat dirasakan sebagaimana dan sejauh apa karyawan meyakini organisasi menghargai kontribusi mereka dan kepedulian dengan kesejahteraan mereka (Robbins \& Judge, 2008). Menurut teori untuk dukungan organisasi, persepsi akan adanya dukungan organisasi tercipta oleh kecenderungan karyawan untuk menempatkan organisasi seperti karakteristik manusia.

Bedasarkan analisis Rhoades dan Eisenberger (2002), terdapat tiga indikator persepsi dukungan organisasional yaitu sebagai berikut: a). fairness (keadilan). Keadilan merupakan suatu hal yang dapat diciptakan. Sebuah keadilan dapat tercipta apabila seorang pemimpin organisasi memiliki kebijaksanaan dalam melakukan pengendalian terhadap sumber daya manusia yang bekerja di dalamnya. Selain itu, apabila sebuah organisasi atau perusahaan dapat berlaku adil kepada seluruh para pekerja di dalamnya maka pada akhirnya dapat tercipta sebuah lingkungan positif di dalam organisasi atau perusahaan tersebut, b). supervisor support (dukungan atasan); Karyawan menciptakan persepsi umum berdasarkan bagaimana pengawas menilai kontribusi, dan peduli akan kesejahteraan karyawan. Pengawas yang bertindak sebagai agen langsung dari organisasi memiliki wenenang dan tanggung jawab didalam pengevaluasian kinerja dan mengarahkan karyawan. Petunjuk dukungan organisasional berupa orientasi atasan atau pengawas yang memberi dampak baik atau tidak terhadap karyawan, c) penghargaan dan kondisi kerja. Praktek dalam sumber daya manusia mengindikasikan kontribusi individu yang seharusnya memiliki hubungan positif dengan persepsi dukungan organisasional (Shore \& Shore, 1995 dalam Rhoades dan Eisenberger, 2002). Berbagai penghargaan dan bentuk kondisi 
kerja yang berhubungan dengan dukungan organisasi antara lain: Pengakuan, gaji, dan promosi; Keamanan dalam bekerja; Otonomi; Role Stressor; Pelatihan; dan Ukuran organisasi.

Keadilan organisasi merupakan suatu hal yang memiliki keterkaitan dengan pandangan pegawai yang bekerja di dalamnya. Keadilan meliputi bagaimana cara organisasi atau perusahaan bersikap adil kepada seluruh para pekerja di dalamnya. Bersikap adil bukan hanya perihal cara berprilaku namun dalam pemberian gaji, kenaikan jabatan dan sejenisnya juga perlu diperhitungkan, sehingga pada akhirnya para pekerja dapat meningkatkan kualitas kinerjanya. Kualitas kinerja pegawai yang meningkat tentu dapat memberikan pengaruh terhadap produktivitas organisasi atau perusahaan.

Indikator variabel keadilan organisasional dalam penelitian ini, mengarah pada Robbins (2006) dan Al-Zu'bi (2010) yaitu: a). keadilan distributif (distributive justice) yang berfokus pada keadilan yang dirasakan oleh responden berdasarkan hasil akhir yang mereka peroleh dari organisasi. Indikator ini diukur dari persepsi responden mengenai penjadwalan kerja, beban kerja, dan imbalan yang mereka peroleh di tempat kerja. b). keadilan prosedural (procedural justice) yang mengacu pada keadilan yang dirasakan responden dari suatu aturan dan prosedur yang mengatur suatu proses dalam organisasi. Indikator ini dilihat dari bagaimana persepsi responden mengenai keputusan yang dilakukan oleh pimpinan, kemudian pimpinan mendengarkan masalah karyawan sebelum membuat suatu keputusan, pimpinan juga mencari informasi yang akurat dan lengkap sebelum membuat keputusan tersebut, dan setelah itu pimpinan menyediakan informasi tambahan ketika dibutuhkan oleh karyawan, keputusan kerja diterapkan secara konsisten kepada seluruh karyawan, dan c). keadilan interaksional (interactional justice) yang mengacu pada keadilan yang dirasakan oleh responden terhadap perlakuan pimpinan kepada karyawan seperti ketika pimpinan memperlakukan karyawan secara terhormat dan bermartabat. Indikator ini dilihat dari persepsi responden mengenai perlakuan pimpinan saat membuat keputusan kerja, pimpinan mempertimbangkan hak-hak karyawan serta implikasi dan justifikasi dalam keputusan kerja.

Menurut Meyer dan Allen (1990), komitmen afektif adalah tingkat keterikatan secara psikologis dengan organisasi berdasarkan seberapa baik perasaan mengenai organisasi yang didasari oleh adanya kenyamanan, keamanan, dan manfaat lain yang diasakan dalam organisasi yang tidak ada di organisasi lain. Komitmen afektif adalah salah satu bentuk dari komitmen organisasi. Komitmen afektif dapat digambarkan dengan seorang karyawan yang menunjukkan rasa memiliki kepada organisasi (ikatan emosional), peningkatan keterlibatan didalam aktivitas, dan keinginan mencapai tujuan, serta keinginan untuk tetap bertahan didalam organisasi. Komitmen afektif merupakan sebuah motivasi yang harus dimiliki oleh karyawan untuk bekerja di dalam sebuah organisasi, karena mereka akan berkenan dan memiliki keinginan untuk melakukan tanggung jawab untuk selalu meningkatkan kinerja mereka

Kinerja atau prestasi kerja adalah hasil kerja yang diukur berdasarkan kualitas dan kuantitas yang telah di gapai oleh seorang karyawan dalam melaksanakan tugasnya sesuai dengan tanggung jawab yang telah diberikan kepadanya (Mangkunegara, 2005). Kinerja merupakan hasil kerja baik secara kualitas maupun kuantitas yang telah dihasilkan karyawan atau perilaku nyata yang ditunjukan sesuai dengan tanggung jawab yang diberikan kepadanya. Indikator untuk mengukur kinerja karyawan menurut Mathis dan Jackson (2006) adalah sebagai berikut ; a). kuantitas, Kuantitas kerja merupakan suatu hal yang memiliki keterkaitan dengan produktivitas kerja. Produktivitas kerja para pekerja dapat dilihat dari upaya yang dilakukan oleh pegawai dalam menghasilkan produk sesuai dengan kebutuhan, b). kualitas, 
Kualitas kerja merupakan suatu upaya yang dilakukan oleh para pekerja sehingga pada akhirnya segala pekerjaan yang dilakukan dapat memiliki kesesuaian dengan standar perusahaan, c). keandalan, Keandalan kerja merupakan suatu hasrat yang diciptakan oleh para pekerja agar dapat melaksanakan aktifitas kerja dengan baik dan sebagaimana mestinya, d).kehadiran, Kehadiran merupakan suatu hasrat yang diciptakan oleh para pekerja agar dapat masuk kerja setiap hari sesuai dengan aturan yang berlaku dan e). kemampuan bekerja sama, Kemampuan bekerja sama merupakan suatu hasrat yang diciptakan oleh para pekerja agar dapat bekerja sama dengan para pekerja lainnya untuk menyelesaikan suatu pekerjaan.

Berdasarkan kajian teori yang telah diuraikan diatas maka terdapat keterkaitan antara variabel variabel persepsi dukungan organisasi, keadilan organisasi, komitmen afektif, terhadap kinerja karyawan yang dapat digambarkan sebagai berikut:

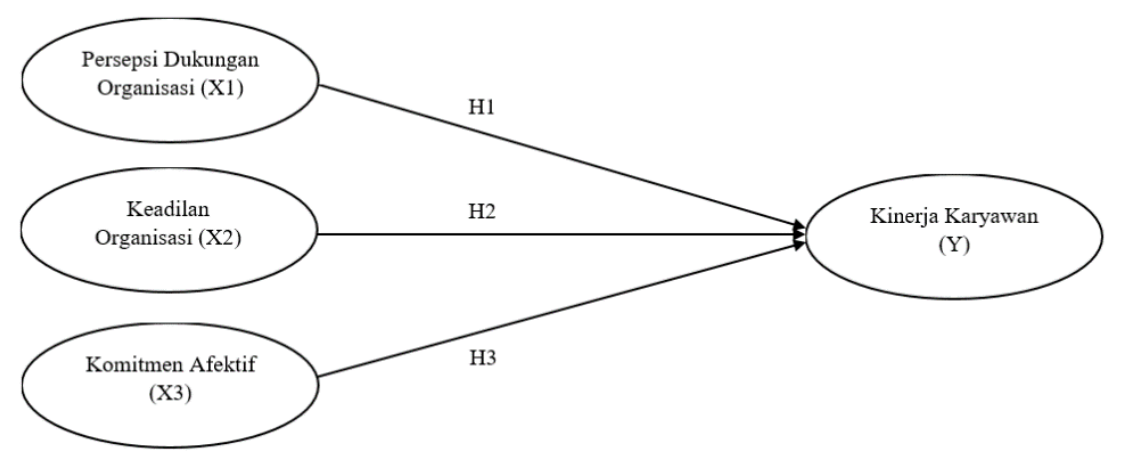

Gambar 1 Model Penelitian

Berdasarkan model penelitian di atas, maka dapat dirumuskan hipotesis penelitian sebagai berikut:

H1 : Persepsi dukungan organisasi mempunyai pengaruh positif dan signifikan terhadap kinerja karyawan

H2 : Keadilan organisasi mempunyai pengaruh berpengaruh positif dan signifikan terhadap kinerja karyawan

H3 : Komitmen afektif mempunyai pengaruh positif dan signifikan terhadap kinerja karyawan

\section{METODOLOGI}

Penelitian ini menggunakan metode penelitian kuantitatif dengan analisis data yang memiliki sifat kuantitatif atau statistik. Populasi pada penelitian ini adalah seluruh guru di Sekolah Methodist Banda Aceh berjumlah 62 orang. Subjek yang diteliti adalah keseluruhan guru di Sekolah Methodist Banda Aceh mulai dari TK, SD, SMP, dan SMA. Data yang digunakan adalah data primer yang diperoleh dengan pengumpulan data menggunakan kuesioner melalui google form terhadap karyawan di Sekolah Methodist Banda Aceh dan tanggapannya diberikan skor berupa skala likert yang besarnya antara 1-5.

Penelitian ini menggunakan tiga variabel independen yaitu persepsi dukungan organisasi, keadilan organisasi, dan komitmen afektif. Variabel persepsi dukungan organisasi memiliki 10 indikator yang diadaptasi dari Rhoades dan Eisenberger (2002), keadilan organisasi 10 indikator yang diadaptasi dari Robbins (2006), dan komitmen afektif 4 indikator yang 
diadaptasi dari Rhoades dan Eisenberger (2002). Variabel dependen pada penelitian ini adalah kinerja karyawan dengan 10 indikator yang diadaptasi dari Mathis dan Jackson (2006).

Data dianalisis menggunakan PLS-SEM yang diolah dengan program software SmartPLS 3.2. Dalam pengujian ini terdapat uji outer model dan uji inner model.

\section{HASIL ANALISIS DATA}

Pengujian validitas data dalam penelitian ini diukur menggunakan nilai validitas konvergen, Average Variance Extracted (AVE), dan validitas diskriminan. Nilai loading factor dikatakan valid apabila lebih dari 0.7. Apabila kurang dari nilai tersebut maka harus dieliminasi, terdapat beberapa indikator yang harus dieliminasi yaitu: PDO8, PDO10, KO7, KO9, KK6, dan KK10. Berikut adalah gambar keluaran PLS Algoritm setelah dilakukan eliminasi dari indikator yang tidak valid:

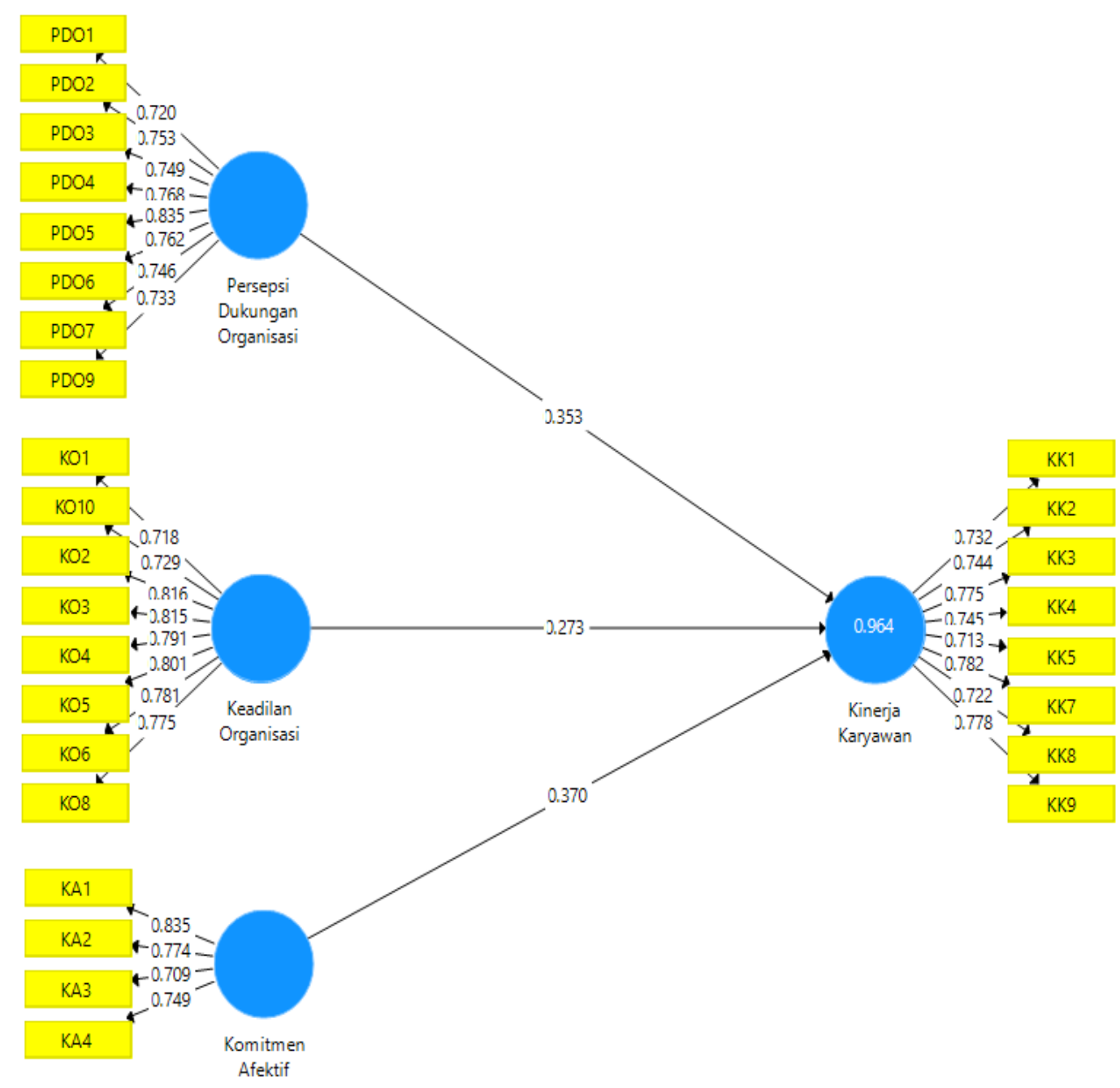

Gambar 2 Hasil Analisis PLS Algorithm 
Selanjutnya pengukuran nilai AVE atau Average Variance Extracted. Nilai AVE harus lebih besar dari 0.5 agar dapat dinyatakan valid.

Tabel 1 Hasil Uji Average Variance Extracted (AVE)

\begin{tabular}{|c|c|}
\hline Variabel & Average Variance Extracted (AVE) \\
\hline Persepsi Dukungan Organisasi & 0.576 \\
\hline Keadilan Organisasi & 0.607 \\
\hline Komitmen Afektif & 0.590 \\
\hline Kinerja Karyawan & 0.562 \\
\hline
\end{tabular}

Berdasarkan tabel di atas diketahui bahwa semua instrumen dalam penelitian memiliki nilai AVE lebih besar dari 0.5. Dengan demikian semua instrumen dalam penelitan ini adalah valid.

Tabel 2 Hasil Uji Reabilitas

\begin{tabular}{|c|c|c|}
\hline Variabel & $\begin{array}{c}\text { Cronbach's } \\
\text { Alpha }\end{array}$ & $\begin{array}{c}\text { Composite } \\
\text { Reliability }\end{array}$ \\
\hline Persepsi Dukungan Organisasi & 0.894 & 0.916 \\
\hline Keadilan Organisasi & 0.907 & 0.925 \\
\hline Komitmen Afektif & 0.767 & 0.852 \\
\hline Kinerja Karyawan & 0.888 & 0.911 \\
\hline
\end{tabular}

Uji reliabilitas instrumen yang digunakan adalah menggunakan Cronbach's Alpha dan Composite Reliability. Suatu instrumen dikatakan reliabel jika diketahui bahwa semua variabel memiliki nilai cronbach's alpha di atas 0,6 dan composite realibility di atas 0,7 . Dengan nilai tersebut, maka dapat disimpulkan bawa data pada penelitian ini reliabel karena telah memenuhi kriteria dan dapat dikatakan reliabel.

Tabel 3 Hasil Uji Inner Model

\begin{tabular}{|c|c|}
\hline Variabel & Hasil \\
\hline R Square & 0.964 \\
\hline Normed Fit Index & 0.631 \\
\hline Predictive Relevance $\left(\mathrm{Q}^{2}\right)$ & 0.527 \\
\hline
\end{tabular}

Uji koefisien determinasi atau analisis $R$ square digunakan untuk mengetahui besar pengaruh variabel independen terhadap variabel dependen tersebut. Nilai $R$ square dari variabel Persepsi Dukungan Organisasi, Keadilan Organisasi, Komitmen Afektif terhadap Kinerja Karyawan adalah 0.964. Artinya, variabel Kinerja Karyawan dapat dikontribusikan sebesar 96.4\% oleh variabel Persepsi Dukungan Organisasi, Keadilan Organisasi, dan Komitmen Afektif, sedangkan sisanya 3.6\% dipengaruhi oleh variabel lain. Uji Goodness of Fit (GoF) dinilai berdasarkan Normed Fit Index (NFI) menunjukkan angka 0.631, sudah berada diantara nilai 0 dan 1 , yang artinya telah memenuhi kelayakan model. Berdasarkan hasil Predictive Relevance $\left(\mathrm{Q}^{2}\right)$ dari variabel Persepsi Dukungan Organisasi, Keadilan Organisasi, dan Komitmen Afektif terhadap Kinerja Karyawan adalah sebesar 0.527 ( $>0)$ yang berarti nilainilai yang diobservasi pada kausalitas direkontruksi dengan baik. 
Pengujian hipotesis dilakukan dengan menggunakan metode bootstrapping. Pengujian hipotesis dilakukan dengan membandingkan nilai p-value dengan tingkat kepercayaan $(\alpha)$ sebesar 0,05. Koefisien jalur adalah signifikan apabila nilai $\mathrm{p}$-value $<0,05$, dan nilai $t$ statistic $>1,96$. Berikut adalah hasil keluaran PLS bootstrapping

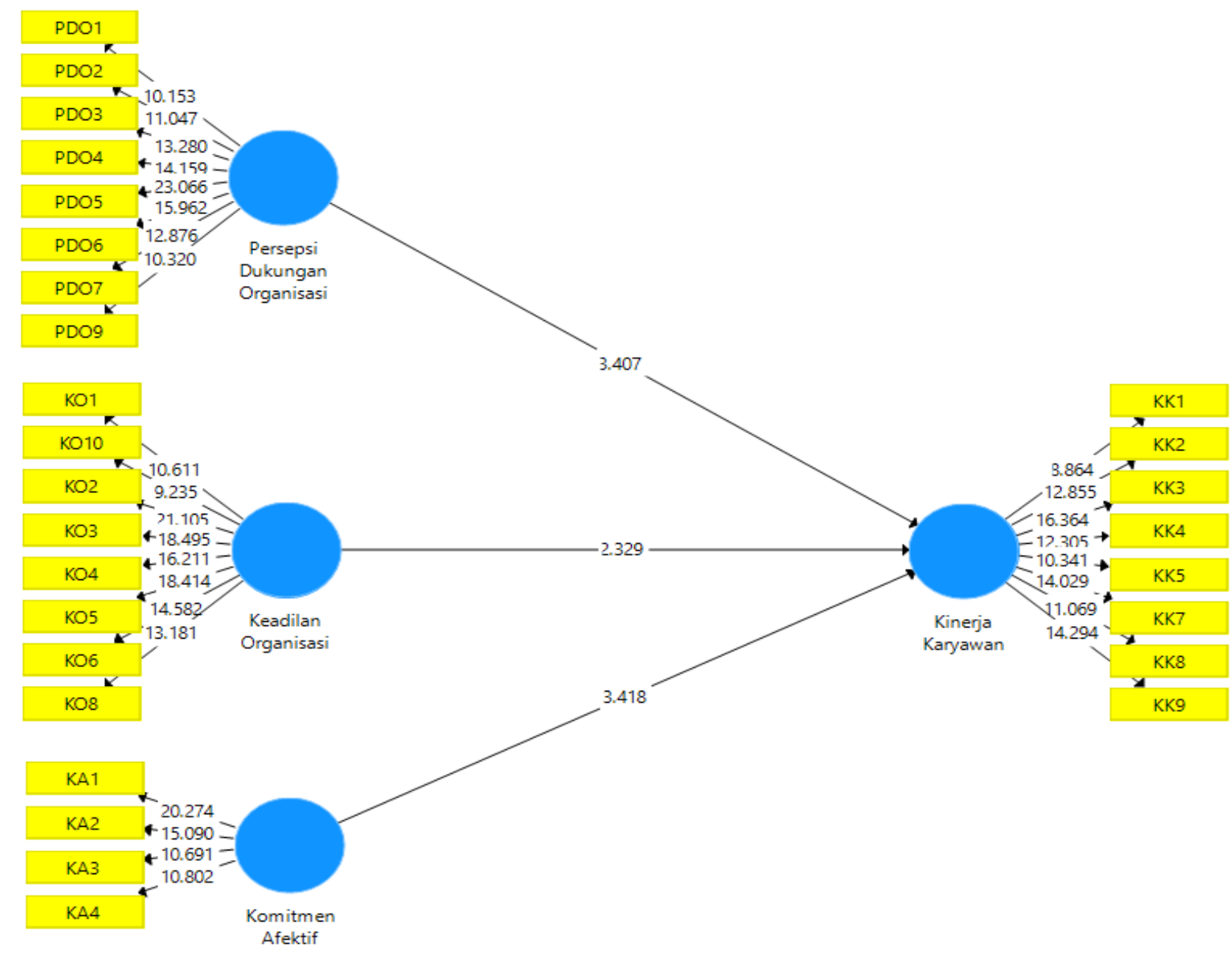

Gambar 2. Hasil analisis PLS bootstrapping

Uji koefisien jalur dan uji hipotesis selenhgkapnya ditampilkan dalam tabel 4 berikut

Tabel 4 Hasil Uji Hipotesis

\begin{tabular}{|c|l|c|c|c|c|}
\hline Ket. & \multicolumn{1}{|c|}{ Pengaruh Variabel } & $\begin{array}{c}\text { Original } \\
\text { Sample } \\
(\boldsymbol{O})\end{array}$ & $\begin{array}{c}\text { T Statistics } \\
(\mid \mathbf{O} / \text { STDEV })\end{array}$ & $\begin{array}{c}\mathbf{P} \\
\text { Values }\end{array}$ & Kesimpulan \\
\hline H1 & $\begin{array}{l}\text { Persepsi Dukungan } \\
\text { Organisasi } \rightarrow \text { Kinerja } \\
\text { Karyawan }\end{array}$ & 0.353 & 3.407 & 0.001 & Diterima \\
\hline H2 & $\begin{array}{l}\text { Keadilan Organisasi } \rightarrow \\
\text { Kinerja Karyawan }\end{array}$ & 0.273 & 2.329 & 0.020 & Diterima \\
\hline H3 & $\begin{array}{l}\text { Komitmen Afektif } \rightarrow \\
\text { Kinerja Karyawan }\end{array}$ & 0.370 & 3.418 & 0.001 & Diterima \\
\hline
\end{tabular}


Hasil pengujian untuk hipotesis pertama menyatakan bahwa pengaruh persepsi dukungan organisasi terhadap kinerja karyawan memberikan nilai original sample $(\mathrm{O})$ sebesar 0.353 yang menujukkan terdapat pengaruh positif dan nilai t-statistik yang didapat sebesar 3.407 (>1.96) dan $p$-values sebesar $0.001(<0.05)$ yang berarti signifikan. Maka dapat disimpulkan bahwa terdapat pengaruh positif dan signifikan persepsi dukungan organisasi terhadap kinerja karyawan sehingga $\mathrm{H} 1$ diterima.

Pada hipotesis kedua untuk melihat pengaruh keadilan organisasi terhadap kinerja karyawan diperoleh nilai original sample $(\mathrm{O})$ sebesar 0.273 yang menujukkan terdapat pengaruh positif dan nilai t-statistik yang didapat sebesar $2.329(>1.96)$ dan $p$-values sebesar $0.020(<0.05)$ yang berarti signifikan. Maka dapat disimpulkan bahwa terdapat pengaruh positif dan signifikan keadilan organisasi terhadap kinerja karyawan sehingga $\mathrm{H} 2$ diterima.

Pengujian pada hipotesis ketiga yang menjelaskan pengaruh komitmen afektif terhadap kinerja karyawan diperoleh nilai original sample $(\mathrm{O})$ sebesar 0.370 yang menujukkan terdapat pengaruh positif dan nilai t-statistik yang didapat sebesar $3.418(>1.96)$ dan $p$-values sebesar $0.001(<0.05)$ yang berarti signifikan. Jadi dapat disimpulkan bahwa terdapat pengaruh positif dan signifikan komitmen afektif terhadap kinerja karyawan sehingga H3 diterima.

\section{DISKUSI}

Persepsi Dukungan Organisasi berpengaruh secara positif dan signifikan terhadap Kinerja Karyawan. Hal ini menunjukkan bahwa apabila persepsi dukungan organisasi semakin baik maka kinerja karyawan juga semakin meningkat. Persepsi dukungan organisasi di Sekolah Methodist Banda Aceh tergolong baik mulai dari keadilan, dukungan atasan, serta penghargaan dan kondisi kerja. Tingginya persepsi dukungan organisasi ini diikuti dengan kinerja karyawan di Sekolah Methodist Banda Aceh sehingga membuktikan adanya pengaruh secara positif dan signifikan dari persepsi dukungan organisasi. Hasil penelitian ini sejalan dengan penelitian yang dilakukan oleh Rismanto (2020), Mujibburahman et.al (2020)., Ariarni dan Afrianty (2017), Murniasih \& Sudarma (2016), dan Agustiningrum (2016) yang menyatakan bahwa persepsi dukungan organisasi berpengaruh positif dan signifikan terhadap kinerja karyawan. Namun bertentangan dengan penelitian dari Purnami (2017).

Keadilan Organisasi berpengaruh positif dan signifikan terhadap Kinerja Karyawan berarti semakin tinggi keadilan organisasi, maka semakin baik juga kinerja karyawannya. Keadilan dalam sebuah organisasi baik itu keadilan distributif, keadilan prosedural, dan keadilan interaksional memang sangat penting dan mempengaruhi kinerja karyawan secara signifikan. Organisasi yang memiliki tingkat keadilan organisasi yang tinggi akan memiliki karyawan yang berkinerja baik juga. Sebaliknya, organisasi yang memiliki tingkat keadilan organisasi yang rendah, karyawan akan memiliki kinerja yang lemah. Pada penelitian ini, keadilan organisasi yang ada di Sekolah Methodist Banda Aceh tergolong baik sehingga kinerja karyawannya juga baik. Hal ini sejalan dengan penelitian yang dilakukan oleh Mujibburahman, et al (2020), Kholis (2017), dan Razi (2019) yang dalam penelitiannya menyimpulkan bahwa keadilan organisasi berpengaruh secara positif dan signifikan terhadap kinerja karyawan. Namun hal ini tidak sejalan dengan penelitian yang dilakukan oleh Fazjerin (2018) yang mengatakan bahwa keadilan distributif dan prosedural tidak berpengaruh signifikan terhadap kinerja karyawan.

Komitmen Afektif berpengaruh positif dan signifikan terhadap Kinerja Karyawan. Hal ini berarti semakin tinggi komitmen afektif seorang karyawan berarti kinerja juga semakin tinggi. Seperti yang diketahui, komitmen afektif mempengaruhi dari segi emosional seseorang, seperti: karyawan merasa merupakan bagian dari organisasi, memiliki rasa keterlibatan yang 
besar, dan ingin turut mencapai tujuan bersama, dan ingin tetap bekerja di organisasi. Tingginya komitmen afektif disebabkan karena Sekolah Methodist Banda Aceh awalnya merupakan organisasi di Gereja yang memiliki visi dan tujuan yang sama untuk berkontribusi di bidang pendidikan dengan harapan dapat menciptakan sumber daya manusia yang kompeten dan berkarakter Kristiani. Hal ini sejalan dengan penelitian yang dilakukan oleh Mohamad \& Tony Nawawi (2020), Avera \& Tony Nawawi (2019), Purnami (2017), Akbar dkk (2017), Murniasih \& Sudarma (2016), dan Anisah (2016) yang menemukan pengaruh positif dan signifikannya komitmen organisasi terhadap kinerja karyawan. Namun hasil ini bertentangan dengan penelitian yang dilakukan oleh Dewi (2019) yang mengatakan bahwa komitmen afektif tidak berpengaruh signifikan terhadap kinerja karyawan.

\section{PENUTUP}

Hasil pengujian, menyimpulkan bahwa: persepsi dukungan organisasi berpengaruh positif dan signifikan terhadap kinerja karyawan Sekolah Methodist Banda Aceh; keadilan organisasi berpengaruh positif dan signifikan terhadap kinerja karyawan Sekolah Methodist Banda Aceh; dan komitmen afektif berpengaruh positif dan signifikan terhadap kinerja karyawan Sekolah Methodist Banda Aceh. Berdasarkan indikator-indikator yang digunakan untuk mengukur setiap variabel yang digunakan pada penelitian ini, terdapat beberapa saran yang dapat diberikan antara lain sebagai berikut: Bagi Sekolah Methodist Banda Aceh, a).Dukungan pimpinan kepada karyawan sudah berjalan baik, tetapi pimpinan diharapkan dapat memberikan beban pekerjaan yang sesuai dan lebih menghargai pendapat dari dari karyawannya. b).Pimpinan sudah bersikap adil, tetapi pimpinan sekolah harus lebih kooperatif dalam memberikan penjelasan dan informasi yang dibutuhkan oleh karyawannya. c).Pimpinan agar dapat menjaga dengan baik komitmen afektif yang sudah dimiliki oleh seluruh karyawannya.

Selain itu, penelitian selanjutnya diharapkan dapat menambah variabel lain yang belum diteliti, contohnya iklim organisasi, produktivitas kerja, kompensasi, kepemimpinan, dan variabel variabel lainnnya serta dapat mengeksplorasi faktor-faktor yang mempengaruhi kinerja karyawan untuk organisasi yang berbeda, sehingga dapat memberikan kesimpulan yang berbeda pula.

\section{DAFTAR PUSTAKA}

Agustiningrum, Sherly Dwi. 2016. Pengaruh Persepsi Dukungan Organisasi Terhadap Kinerja Karyawan Yang Dimediasi Oleh OCB (Organizational Citizenship Behavior) (Studi pada PT. Angkasa Pura I Kantor Cabang Surabaya)

Akbar, Amirul, Mochammad Al Musadieq, dan Mochammad Djudi Mukzam. 2017. Pengaruh Komitmen Organisasional Terhadap Kinerja (Studi Pada Karyawan PT. PELINDO Surabaya)

Al-zu'bi, h. (2010). A Study of Relationship Between Organizational Justice and Job Satisfaction. International Journal of Business and Management.

Anisah. 2016. Pengaruh Komitmen Afektif, Normatif dan Kontinuan Terhadap Kinerja Karyawan Pada PT. Summit Oto Finance, Tbk Cab. Jambi

Ariarni, Nurmalia dan Tri Wulida A. 2017. Pengaruh Perceived Organizational Support terhadap Kinerja Karyawan dengan Employee Engagement Sebagai Variabel Intervening (Studi pada Karyawan PT. Pos Indonesia Kota Madiun)

Avera, Stella Karunia dan M. Tony Nawawi. 2019. Pengaruh Budaya Organisasi dan Kepuasan Kerja terhadap Kinerja Karyawan dan Komitmen Organisasi sebagai Variabel Mediasi 
pada PT. Tiki Jalur Nugraha Ekakurir Jakarta. Jurnal Manajerial dan Kewirausahaan, Volume I No. 4 Hal: 811-819.

Dewi, Prima Aprilia. 2019. Komitmen Afektif, Normatif, dan Berkelanjutan Yang Mempengaruhi Kinerja Karyawan (Studi pada PT. Great Giant Pinapple Department Labelling and Packaging Lampung Tengah)

Fatdina. 2009. Peran Dukungan Organisasi Yang Dirasakan Karyawan Sebagai Mediator Pengaruh Keadilan Prosedural Terhadap Perilaku Kewarganegaraan Organisasi. Jurnal Psikologi, 36(1), 1-17.

Fazjerin, Ansori. 2018. Pengaruh Keadilan Organisasi Dan Leader-Member Exchange Terhadap Kinerja Karyawan Dengan Komitmen Afektif Sebagai Variabel Intervening (Studi Pada Karyawan Universitas Swasta di Provinsi Bengkulu)

Han, Sia Tjun., et al 2012. Komitmen Afektif dalam Organisasi yang Dipengaruhi Perceived Organizational Support dan Kepuasan Kerja. Jurnal Manajemen dan Kewirausahaan. Volume 14. No. 2. Halaman 109-117.

Kholis, R.N. 2018. Pengaruh Keadilan Organisasi Terhadap Kinerja Karyawan PT. Aksara Solopos

Mangkunegara, Anwar Prabu. 2005. Evaluasi Kinerja Sumber Daya Manusia. Bandung: Refika Aditama.

Mangkunegara, Anwar Prabu. 2008. Manajemen Sumber Daya Manusia. Bandung: PT. Remaja Rosda Karya.

Mathis, R.L. \& J.H. Jackson. 2006. Human Resource Management: Manajemen Sumber Daya Manusia. Terjemahan Dian Angelia. Jakarta: Salemba Empat.

Meyer, J.P. dan Allen, N.J. 1990. A Three-Component Conceptualization of Organizational Commitment. Human Resource Management.

Mohamad, Rahadian dan M. Tony Nawawi. 2020. Pengaruh Organizational Learning, Organizational Commitment dan Job Satisfaction Terhadap Employee Performance di Jakarta. Jurnal Manajerial dan Kewirausahaan, Volume II No. 4. Hal: 1060-1069

Mujibburahman, et al. 2020. Pengaruh Dukungan Organisasi terhadap Kinerja Dimediasi oleh Keadilan Organisasi

Murniasih, Emi \& Ketut Sudarma. 2016. Management Analysis Journal 5 (1) 35 Pegawai pada Sekda Provinsi Papua. Jurnal Aplikasi Manajemen. Volume 10. Nomor 2. Halaman 262272

Panggabean. (2004). Penilaian Kinerja. (online), (Http:www:LPTUI.com)

Purnami, Putu Ria. 2017. Pengaruh Kompensasi dan Persepsi Dukungan Organisasi Terhadap Komitmen Organisasi dan Kinerja Karyawan Rumah Sakit BaliMéd Karangasem

Razi, Fakhrul. 2019. Pengaruh Keadilan Organisasi terhadap Kinerja Pegawai Dengan Komitmen Afektif Sebagai Variabel Mediasi Pada Kantor Pusat Administrasi Universitas Syiah Kuala

Rhoades, L. \& Eisenberger, R. 2002. Perceived organizational support: A review of the literature. Journal of Applied Psychology, 87(4), 698-714

Rismanto. 2020. Pengaruh Persepsi Dukungan Organisasi terhadap Kinerja Karyawan Dengan Keterlibatan Karyawan Sebagai Variabel Mediasi (STUDI DI UNIVERSITAS SARJANAWIYATA TAMANSISWA YOGYAKARTA)

Robbins, Stephen P. 2006. Perilaku Organisasi. Edisi Sepuluh. Diterjemahkan oleh: Drs. Benyamin Molan. Jakarta: Erlangga

Robbins, Stephen P. \& Timothy A. Judge. 2008. Perilaku Organisasi. Edisi ke-12. Jakarta: Salemba Empat. 
Setyaningdyah, Endang, Kertahadi Umar Nimran, dan Armanu Thoyib. 2013. The Effects of Human Resource Competence, Organisational Commitment and Transactional Leadership on Work Discipline, Job Satisfaction and Employee's Performance. Interdisciplinary journal of contemporary research in business. Indonesia: Brawijaya University.

Shore, L. M., \& Shore, T. H. (1995). Perceived organizational support and organizational justice, In R. Cropanzano \& K.M. Kacmar (Eds). Organizational politics, justice, and support: Managing social climate at work (pp.285-305). Westport, CT. Quorum Press.

Sutrisna, I Wayan Wira dan Agoes Ganesha Rahyuda. 2014. Pengaruh Keadilan Distributif, Prosedural, dan Interaksional Terhadap Kepuasan Kerja Dan Komitmen Organisasi Pada Paramedis Di Rumah Sakit Tk II Udayana Denpasar. E-Journal Manajemen Universitas Udayana, 3 (9). 